\title{
Worlds of last-resort safety nets? A proposed typology of minimum income schemes in Europe
}

\author{
Marcello Natili (marcello.natili@unimi.it) \\ Accepted for publication \\ Journal of International and Comparative Social Policy
}

\begin{abstract}
Over the past twenty years, minimum income schemes (MIS) have undergone major transformations in their functions and role. From mainly residual instruments that aimed to guarantee minimum income support and to prevent extreme marginality, in most countries they now have an "ambiguous" function of providing income support and favouring social and labour market inclusion. Against this background, this article provides an analytical grid that allows describing the different features of last-resort safety nets across Europe, building on the definition of key main dimensions of variation of MISs in Europe generosity, eligibility and conditionality requirements, institutional configuration, active inclusion profiles. Then, it introduces a new typology of MIS in Europe, building on a new dataset with data on expenditures and coverage collected from National Statistical Offices.
\end{abstract}

Keywords: Minimum Income Schemes, Poverty, Activation, Welfare Regimes.

\section{Introduction}

Over the past twenty years, minimum income schemes ${ }^{1}$ (MIS) have undergone major transformations in their functions and role (Lodemel and Moreira, 2014). From mainly residual instruments that aimed to guarantee minimum income support and to

1 In this article, I adopt a strict definition of MIS that does not cover the entire range of social assistance benefits but only anti-poverty benefit for the working-age population. Here, MISs are thus non-categorical, anti-poverty schemes providing rights-based means-tested income support, that are typically flat-rate and tax financed. Relevantly, this definition of MIS excludes in-work benefits i.e. means-tested benefit specifically targeted to employees, such as the Working Tax Credit in the UK, or means-tested child benefits. 
prevent extreme marginality, in most countries they now have an "ambiguous" function - promoted by the active inclusion paradigm introduced by the European Union (Ferrera and Jessoula, 2016) - of providing income support and favouring the empowerment of poor individuals and their social inclusion. Countries across Europe have realized and implemented this function very differently, and, although in some countries it has mostly translated into stricter conditionality of means-tested benefits on job search activities, in others it has assumed a broader "reintegrative" and enabling scope.

This differentiated evolution in the goals and scope of minimum income schemes in Europe has been associated with increasing programme variation. However, this policy development cannot be fully captured with the analytical lenses used to build traditional social assistance typologies (Lodemel and Schulte 1992; Gough et al. 1997; Bahle et al. 2011). Indeed, as noticed by Moreira (2008), these categorizations focused on dimensions (generosity, expenditure, coverage, extent of discretion in the provision of the benefit, territorial governance, eligibility conditions, individual vs household entitlement, conditionality requirements) that provide little information on the role of minimum income schemes in the broader framework of welfare provision, whereas it is necessary to consider their different roles in the overall income maintenance system. Furthermore, nowadays, minimum income systems deviate from each other in one other crucial dimension, as they have country-specific conditionality and active inclusion profiles (Marchal and Van Mechelen, 2017).

Against this background, this article provides an analytical grid that allows describing the different features of 'new' last-resort safety nets across Europe building on original data. Combining information related to protectiveness of last resort safety nets with others concerning their activation profile, it contributes to unveil the very 
nature of today's MISs. Furthermore, it illustrates that nowadays 'worlds of last-resort safety nets' differ extensively with respect to traditional welfare state typologies (Esping-Andersen, 1990; Ferrera et al. 2000). Conversely, established social assistance categorizations (Lodemel and Schulte 1992; Gough et al. 1997), despite highlighting some degree of diversification among Continental countries, widely reflected the distinction between the welfare regimes identified by Esping-Andersen with the addition of the 'Southern European' model ${ }^{2}$ (Moreira 2008).

The paper is structured as follows. The following section briefly retraces the history of the evolution of means-tested benefits in Europe. The third section introduces the main dimensions of variation in MIS. In particular, it illustrates the different roles played by last-resort safety nets in different countries, taking into consideration different institutional configurations of income maintenance systems in Europe. Subsequently, it focuses on "outcome" indicators, providing a description of different MISs according to three crucial standard dimensions (Bahle et al., 2011): generosity, coverage, and overall expenditure. The fourth section introduces another dimension of variation, the active inclusion profile of MISs, providing a classification of different activation models. The fifth section introduces a typology of MIS in Europe, while the sixth concludes.

\footnotetext{
${ }^{2}$ In particular, one of the most comprehensive of these studies (Gough et al. 1997), identified five different social assistance clusters in Europe. These are the "Welfare states with integrated safety nets' (Ireland and the United Kingdom), in which MISs are institutionalised at the national level and cover a significant amount of the population; the 'Dual social assistance' (Germany, France and Belgium), in which exists a general last resort safety net along with measures to protect specific categories; the 'Citizenship with residual social assistance' regime typical of the Scandinavian countries (excluding Norway) and of the Netherlands, in which fully institutionalized MIS have only a residual role; the 'Rudimentary assistance regime' (Greece, Italy, Portugal and Spain), where MISs are provided in a fragmented and uneven manner only at the local level; and, finally, the Discretionary decentralised system (Austria, Norway and Switzerland), in which MISs are discretionary and provided only at the sub-national level.
} 


\section{The Evolution of Minimum Income Schemes in Europe}

Anti-poverty benefits - local and discretionary - were the first (and only) form of public intervention to mitigate social deprivation in most European societies. Dating back to the late nineteenth century, these policies combined a paternalistic approach typical of pre-industrial authoritarian societies with segregating and repressive elements. After all, societies then still mostly viewed social assistance as an instrument of social regulation, aimed at suppressing and preventing cases of deviance rather than fulfilling solidarity and individual support purposes. These benefits were thus occasional, residual, and discretional, involving severe stigmatization of the beneficiaries. It was with the transition from this kind of poor relief and public assistance scheme to the introduction of the first public compulsory social insurance schemes that the modern welfare state emerged (Alber, 1981).

During the 'Golden Age of welfare state expansion' (1945-1975), although remaining in place in most countries, anti-poverty benefits lost most of their functional relevance in a context characterized by economic growth and Keynesian macroeconomic policies that aimed to guarantee full employment. At the same time, the origins of minimum income schemes date back precisely to this period, when last-resort income support schemes dropped the discretionary and ad hoc nature that had characterized them until then to resemble more and more fully fledged enforceable social rights (Ferrera, 2005). Despite different institutional designs, those schemes shared the vocation to serve as a residual layer of social support underneath universal and/or insurance-based social protection arrangements, providing for the "exceptional cases" with unusual needs that in a full-employment economy fell through the net of more comprehensive programmes and remained poor (Clegg, 2013; Nelson, 2003). The main functions of these schemes were thus income support and the prevention of 
extreme marginality. In 1948, the United Kingdom was the first country to introduce a scheme of income support intended to provide sufficient resources to meet the basic life course needs of the worst-off in society; it was later followed by Sweden (1956), Germany (1961), Denmark (1974), Belgium (1974), and Ireland (1975). Some countries opted instead for categorical schemes, directed to specific target groups, primarily the "elderly poor" (cfr. Madama, 2015). Italy followed this route, introducing the social pension in 1969, along with France (1956) and Belgium (1969) and later Portugal (1980) and Spain (1988).

In the late 1980s, a new phase emerged, characterized by the diffusion of safety nets in all European countries and by the emergence of the "activation" paradigm. Following the introduction of the Revenu Minimum d'Insertion in France, all the countries that had originally chosen categorical benefits finally introduced fully fledged MISs. This was the case in Luxembourg (1989), Spain at the subnational level (19891995), and Portugal (1997). Eastern and Central European countries, facing the collapse of the Soviet Union and the slow process of EU enlargement to the East, also gradually introduced minimum income schemes (Rat, 2009). This diffusion of means-tested benefits, aiming to guarantee a minimum amount of resources to those who have insufficient means of subsistence, was concluded only very recently in all EU countries, with the adoption of an MIS in February 2017 in Greece and the introduction of the Inclusion Income in Italy in 2018.

In this phase, in most countries anti-poverty programs deeply transformed from the safety nets of the golden age, leading scholars to speak of a third generation of social assistance programmes (Kazepov, 2010). As part of a broader shift of many European welfare states from transfer-oriented to active-service-oriented welfare (Hemerijk, 2012), in fact, the function and scope of MIS broadened to include social 
inclusion and labour market integration. Under the generally accepted assumptions that "passive" benefits generate disincentives to seek and accept work and that it is only possible to reinstitute "full" citizenship through labour market integration of the "ablebodied" (cfr. Weishaupt, 2012), governments made access to minimum income benefits conditional on job search activities and on programmes that, as their ultimate goal, aimed for labour market (re-)inclusion (Lodemel and Trickey, 2001; Moreira, 2008). As a general rule, they strengthened the conditional ties and duties for beneficiaries, and social services and active labour market programmes became part of the minimum income package to "break the vicious circle of inactivity, obsolete skills and competences, and demotivation".

It is possible to associate this apparent convergence towards selective universalism (Ferrera, 2000) and "active inclusion" partially with the fact that, in the post-industrial scenario, the salience of social assistance benefits has increased. Major transformations in labour market structures and policies - specifically the flexibilization of employment, the spread of atypical jobs, and/or retrenchment in unemployment protection - combined with novel socio-cultural patterns - in particular mounting family instability and more fragile family-kin solidarity ties - have made social assistance a key social protection institution for ordinary European citizens (Marx, 2007; Natili 2019; Rosanvallon, 1995). At the same time, the institutional design of the very last tier of social protection regimes remains largely differentiated across Europe (Bahle et al., 2011; Frazer and Marlier, 2016; Immervol, 2010; Marx and Nelson, 2012) and the country-specific configuration of MISs provides citizens with very different benefits and programmes to countervail poverty. The next paragraphs aim to provide information precisely regarding this dimension - that is, the different structures of MIS in Europe. 


\section{The Dimension of Variation of Minimum Income Schemes in Europe}

\subsection{The institutional role of minimum income schemes.}

To understand the key features of minimum income schemes in a country, it is essential to know which principles of distribution dominate the overall welfare state context (Bahle et al., 2011) and, in particular, the main institutional features of the income maintenance system for the working-age population. A more inclusive and universal unemployment compensation system in fact reduces the relevance of MIS, which conversely becomes a central social policy institution when unemployment benefits are less inclusive and comprehensive.

The institutional configuration of unemployment benefits differs quite extensively across Europe, although signs of greater harmonization have been apparent in the last two decades (for a review, see Clasen and Clegg, 2011; Picot, 2012). They are never formally universalistic but always based on a combination of contributory and meanstested access (Schmid and Reissert, 1996). At the risk of some oversimplification, here (Table 1), I adopt the basic, standard classification of unemployment benefits based on "three pillars" or "levels" (Vesan, 2012), each resulting from specific political struggles at different historical moments (Alber, 1981). The first pillar consists of the standard unemployment insurance, financed by employers' and employees' contributions, so entitlement is conditional on past employment and contribution records. The benefit levels are earnings related, and the durations are limited. General revenues, conversely, finance unemployment assistance - the second pillar; entitlement is usually based only on being unemployed - in some cases, it is also necessary to have an expired possibility to access first-tier unemployment benefits - and always depends on a means test. The 
benefit amounts are generally a flat rate. These first two tiers are sometimes called "dedicated unemployment benefits". Social assistance benefits - that is, minimum income schemes - constitute the third, residual, pillar.

Table 1. The role of minimum income schemes in income maintenance systems

\section{Unemployment insurance (more or less inclusive)}

\begin{tabular}{c|c|c}
\hline $\begin{array}{c}\text { Unemployment assistance } \\
\text { Minimum income } \\
\text { scheme }\end{array}$ & $\begin{array}{c}\text { Minimum income } \\
\text { scheme } \\
\text { scheme }\end{array}$ \\
$\begin{array}{c}\text { AT - CZ - GR - FIN - FR - HU } \\
\text { - PT - SE - SP }\end{array}$ & $\begin{array}{c}\text { Supplementary social } \\
\text { Bssistance schemes for those } \\
\text { unable to work }\end{array}$ \\
\hline
\end{tabular}

Source: Author's elaboration from Picot (2012) and Sacchi (2013).

The financing, governance, and institutional features of these different benefit tiers show great cross-national variation in Europe. Historically, the most typical unemployment compensation system envisaged the presence of all three pillars. In this type of system, MIS were to play a residual role, serving as a last-resort safety net underneath universal and/or insurance-based social protection arrangements, providing for the "exceptional cases" with unusual needs that in a full-employment economy fell through the net of more comprehensive programmes and remained poor (Clegg, 2013). This type of income maintenance system is still in place in many relevant European countries, such as Austria, the Czech Republic, Finland, France, Portugal, Spain, and 
Sweden. In these countries, MISs still play a residual anti-poverty role, albeit increasingly relevant due to the changing nature of the labour market (Marx, 2007).

In other countries, MISs are the only existent income protection scheme for the working-age population beyond a (usually) very inclusive, generous, and (once) longlasting unemployment insurance scheme. This is the case of Belgium, Denmark, Iceland, Luxembourg, and the Netherlands. In these countries, MIS still have mainly an anti-poverty function - even though their relevance depends on the degree of inclusiveness of the first-tier unemployment benefit. In the last decades, in fact, changes in the duration and in the eligibility condition of unemployment benefits have contributed to increasing the relevance of social assistance means-tested benefits in many of these countries (Clasen and Clegg, 2011).

Finally, a different combination of unemployment benefits and social assistance schemes exists in Ireland, the United Kingdom ${ }^{3}$, and, since the famous 2005 "Hartz IV" reform merging unemployment assistance and social assistance (Fleckenstein, 2008), Germany. Here, below a strict - unable to protect all the unemployed and especially atypical workers - unemployment insurance scheme exists a comprehensive minimum income scheme for the able-bodied working-age population that is complemented by a series of categorical and fragmented social assistance benefits for special categories of people. It is fair to say that it is precisely in this third type of configuration that MISs assume the most important role in the income maintenance system, as they protect also many (long-term) unemployed due to the low inclusiveness of 'higher level' unemployment benefits..

\footnotetext{
${ }^{3}$ The UK is indeed a peculiar case, as there is more than one program that can be included in the definition of MIS provided above: the Income-based Jobseeker's Allowance and the Income Support.
} 


\subsection{Generosity}

In Europe, the amount of minimum income benefits generally coincides with the difference between a poverty threshold that a law or administrative decree establishes and the beneficiaries' estimated income. However, the principle for determining the level of this threshold is not as straightforward as it is, for example for unemployment benefits. In Recommendation (C(2008) 5737) adopted in October 2008 on the active inclusion of people excluded from the labour market, the European Commission declared that adequate income support should be "sufficient to lead a life that is compatible with human dignity". Beyond this general (and vague) principle, there is no agreement regarding the definition of an adequate standard, and every country sets a different system to define the minimum income level.

Frazer and Marlier (2016) distinguished between countries where there is a mechanism for establishing the level of payments that is based on a (set of) clearly specified indicator(s) and countries - the majority - where such mechanisms do not exist. Among the former, some countries define their minimum income benefits as a percentage of the social benefits or of the minimum wage. In Portugal, until 2012, the level of the benefit was equal to the social pension. In the Netherlands - as in most Spanish autonomous communities - conversely the amount of the Participatiewet corresponds to a percentage of the minimum wage: single individuals receive $50 \%$ of the minimum wage, single parents receive $70 \%$, and couples receive a transfer that equals $100 \%$ of the minimum wage.

However, in most countries, there is no clear mechanism to establish the benefit amount, and the minimum level is set arbitrarily (politically and/or administratively) every year to cover the basic costs deemed necessary to conduct a decent life, taking 
into consideration food, clothing, housing expenditures, and so on. Having established the basic threshold level for a single person, the benefit amount is parametrized according to different factors, among which the most common is the household composition. In many countries - especially northern and German-speaking continental countries - the scale of equivalence also takes children's age into consideration. Moreover, in those cases, the benefit amount may increase significantly to cover particular individual and household needs and expenses. These are particularly generous in Germany, Finland, and Sweden, where it is possible to receive additional transfers to cover expenditures for rent, heating, electricity, health care and medicines prescribed by a physician, school expenses for children, and transportation costs from and to workplaces (Angelin et al., 2013; Petzold, 2013). Unfortunately, those benefits are very difficult to calculate precisely, since they are often fixed at the local level, so they create within-country differences, they are modulated on specific households' features, and they are usually of a discretionary nature (Marchal et al., 2014). For these reasons, I do not consider them in my comparative description, despite being aware that this might "lower" the generosity of MISs in some countries, especially Germany and Sweden.

Table 2 shows the generosity of minimum income schemes in most European countries in 2015. Following common practice (see for instance Bahle et al., 2011; Marchal and Van Mechelen, 2017; Nelson, 2013), I assess the adequacy of income support through the benefit amount in relation to the relative poverty threshold - namely $60 \%$ of the median equivalized income among the adult population. This type of indicator indicates how much minimum income benefits move close households income to the poverty line. 
Table 2 Generosity of minimum income benefits in Europe, 2015

\begin{tabular}{|c|c|c|c|}
\hline Country & $\begin{array}{l}\text { Basic amount } \\
\text { Percentage of } \\
\text { relative poverty } \\
\text { threshold }\end{array}$ & $\begin{array}{l}\text { Amount for couples } \\
\text { with two children } \\
\text { Percentage of } \\
\text { relative poverty } \\
\text { threshold }\end{array}$ & Generosity \\
\hline Latvia & $17.1 \%$ & $32.50 \%$ & Low \\
\hline Slovakia & $17.8 \%$ & $22 \%$ & Low \\
\hline Bulgaria & $19.9 \%$ & $33 \%$ & Low \\
\hline Estonia & $22.8 \%$ & $41.3 \%$ & Low \\
\hline Italy (2018) & $23.7 \%$ & $30.8 \%$ & Low \\
\hline Romania & $27,6 \%$ & $41,1 \%$ & Low \\
\hline United Kingdom & $37.7 \%$ & $36.7 \%$ & Low \\
\hline Sweden & $33.4 \%$ & $49.4 \%$ & Low (Medium) \\
\hline Czech Republic & $33.9 \%$ & $49.6 \%$ & Low (Medium) \\
\hline Germany & $39.1 \%$ & $60.1 \%$ & Medium \\
\hline Lithuania & $39.4 \%$ & $60 \%$ & Medium \\
\hline Croatia & $39.6 \%$ & $45.2 \%$ & Medium \\
\hline Finland & $40.9 \%$ & $60.9 \%$ & Medium \\
\hline Portugal & $42.2 \%$ & $42.2 \%$ & Medium \\
\hline Slovenia & $43.9 \%$ & $64.8 \%$ & Medium (High) \\
\hline France & $48.9 \%$ & $48.9 \%$ & Medium \\
\hline Greece & $53.2 \%$ & $50.7 \%$ & Medium \\
\hline Spain & $65.3 \%$ & $43.3 \%$ & Medium \\
\hline Ireland & $69.3 \%$ & $65.4 \%$ & High \\
\hline Austria & $72 \%$ & $63.8 \%$ & High \\
\hline Luxembourg & $76.4 \%$ & $61.2 \%$ & High \\
\hline Belgium & $77 \%$ & & High \\
\hline Netherlands & $85.1 \%$ & & High \\
\hline Denmark & $102.50 \%$ & $138 \%$ & High \\
\hline
\end{tabular}

\subsection{Coverage}

The ability of a minimum income scheme to intercept all the people living in poverty depends on a broad range of issues. As the previous paragraphs underlined, in some countries, a fairly inclusive and protective unemployment benefits system has left a residual role to MIS; in others, reforms and retrenchment in upper-tier unemployment benefits have made social assistance benefits an important social protection institution for vulnerable middle-class citizens (Clegg, 2013). Furthermore, countries have different regulations concerning other types of non-contributory benefits - i.e. disability, child, in-work 
and/or housing benefits, etc. - that clearly have an impact on the overall number of beneficiaries of minimum income schemes, so that comparative analysis based on number of recipients should be considered cautiously.

However, the total number of beneficiaries also depends on eligibility conditions, which vary extensively across Europe, with important consequences for poor citizens' possibilities to access social benefits (Figari et al., 2013; Granaglia and Bolzoni, 2016). The most common types of eligibility conditions relate to a lack of financial resources, not having assets above a certain limit, age (e.g. $18+$ or $25+$ ), nationality/citizenship, and/or residence. In many - but not all countries, to access minimum income benefits, individuals need to have exhausted their rights to any other (social) benefits (cfr. Frazer and Marlier, 2016). Beyond these "formal requirements", peculiar administrative requirements might (or might not) create barriers that discourage would-be beneficiaries from advancing a request to access last-resort safety nets. Studies have reported transaction costs, such as difficulties in completing the application form and/or a procedure that individuals consider to be too complex and invasive, as reasons for the low takeup level of minimum income benefits (Eurofound, 2015). Other, have documented that sometimes exist administrative practices to discourage applications from specific groups of would-be beneficiaries, such as migrants (Natili, 2016). Bureaucratic procedures thus affect significantly the total number of social assistance recipients (Eurofound, 2015; Matsaganis et al., 2008).

Table 3. Beneficiaries of MIS programmes in Europe, 2015

\begin{tabular}{|c|c|c|c|}
\hline Country & Programme & $\begin{array}{c}\text { Beneficiaries } \\
\text { Total }\end{array}$ & $\begin{array}{c}\text { Beneficiaries } \\
\text { Percentage of the } \\
\text { population }\end{array}$ \\
\hline
\end{tabular}




\begin{tabular}{|c|c|c|c|}
\hline Austria & $\begin{array}{c}\text { Bedarfsorientierte } \\
\text { Mindestsicherung-BMS }\end{array}$ & 284,374 & $3.30 \%$ \\
\hline Bulgaria & Social assistance & 63,932 & $0.89 \%$ \\
\hline Croatia & $\begin{array}{l}\text { Zajamčena minimalna } \\
\text { naknada }\end{array}$ & 80,714 (households) & $5.20 \%$ \\
\hline Czech Republic & Přispěvek na živobytí & $\begin{array}{c}149,000 \\
\text { (households) }\end{array}$ & $3.41 \%$ \\
\hline Denmark & $\begin{array}{c}\text { Kontanthjælp + } \\
\text { Uddannelseshjælp }\end{array}$ & 199,446 & $3.52 \%$ \\
\hline Estonia & Toimetulekutoetus & 89,950 & $6.80 \%$ \\
\hline Finland & Toimeentulotuki & 400,225 & $7.31 \%$ \\
\hline France & $\begin{array}{l}\text { Revenu de Solidarité } \\
\text { Active (Socle) }\end{array}$ & $3,533,700$ & $5.31 \%$ \\
\hline Germany & Arbeitslosengeld II & $5,993,135$ & $7.38 \%$ \\
\hline Greece $(2017)^{*}$ & Solidarity income & 700,000 & $6.44 \%$ \\
\hline Ireland & Jobseeker allowance & 246,536 & $5.33 \%$ \\
\hline Ireland & $\begin{array}{c}\text { Supplementary welfare } \\
\text { allowance }\end{array}$ & 14,696 & \\
\hline Italy $(2018)^{* *}$ & Inclusion income & 981,688 & $1.6 \%$ \\
\hline Latvia & $\begin{array}{l}\text { Guaranteed minimum } \\
\text { income }\end{array}$ & 34,200 & $1.72 \%$ \\
\hline Lithuania & Social assistance & 110,701 & $3.79 \%$ \\
\hline Netherlands & Uitkering bijstand & 463,000 & $2.74 \%$ \\
\hline Portugal & $\begin{array}{l}\text { Rendimento Social de } \\
\text { Inserção }\end{array}$ & 295,664 & $2.85 \%$ \\
\hline Spain & $\begin{array}{l}\text { Rentas Minimas de } \\
\text { Inserciones de las } \\
\text { Communidades } \\
\text { Autonomas }\end{array}$ & 789,672 & $1.70 \%$ \\
\hline Sweden & Ekonomiskt Bistånd & 415,664 & $4.26 \%$ \\
\hline United Kingdom & $\begin{array}{c}\text { Jobseeker allowance } \\
\text { (means-tested) + Income } \\
\text { Support }\end{array}$ & $\begin{array}{c}598,000+ \\
711000\end{array}$ & $2 \%$ \\
\hline
\end{tabular}

Table 3 reveals the number of beneficiaries in 2015 of means-tested minimum income schemes in most European countries that the national statistical offices collected. These numbers provide useful information regarding the diffusion and relevance of minimum income benefits in a country. However, to obtain a more analytically useful dimension of coverage, in Table 4, I depict the number of beneficiaries as a percentage of the people aged less than 65 living in severe poverty, that is, with an income below $40 \%$ of 
the median average income and not $60 \%$, as it is usually gauged. This type of outcome indicator estimates the ability of last-resort safety nets to intercept people in need, although it does not provide information regarding which factors precisely explain a particularly high or low level of coverage. As mentioned, several factors might in fact contribute to different degrees of inclusiveness of MISs, such as a very low income threshold, behavioural requirements that are too strict, the presence of administrative requirements that might discourage potential applicants, a low take-up level, and so on.

Table 4. Coverage of MISs in European countries, 2015

\begin{tabular}{lcc}
\hline Country & $\begin{array}{c}\text { Beneficiaries as a } \\
\text { percentage of severely poor } \\
\text { individuals less than } 65\end{array}$ & $\begin{array}{c}\text { Degree of } \\
\text { inclusiveness }\end{array}$ \\
\hline Bulgaria & $11.7 \%$ & Low \\
\hline Spain & $16.2 \%$ & Low \\
\hline Italy (2018) & $19.5 \%$ & Low \\
\hline Latvia & $21.8 \%$ & Low \\
\hline Portugal & $36.8 \%$ & Low \\
\hline United Kingdom & $48.6 \%$ & Low \\
\hline Lithuania & $53 \%$ & Low)-medium \\
\hline Greece (2017) & $69.8 \%$ & Medium \\
\hline Denmark & & Medium \\
\hline Sweden & $85.6 \%$ & Medium \\
\hline Netherlands & $93.4 \%$ & Medium \\
\hline Estonia & $96.7 \%$ & Medium \\
\hline Austria & $99.9 \%$ & High \\
\hline & $103 \%$ & High \\
\hline Germany & $174.6 \%$ & High \\
\hline Ireland & $215.5 \%$ & \\
\hline France & $342.1 \%$ & \\
\hline
\end{tabular}

Source: Author's elaboration from the national statistical offices and the Eurostat online database.

Accordingly, I am able to capture three different types of minimum income schemes in relation to their "degree of inclusiveness". The first type protects only a small portion of the people in severe poverty - and for this reason I include it here in the group with a 
low degree of inclusiveness. The second type includes anti-poverty MISs that are able to intercept (most of) the population in severe poverty: this is the case of Denmark, the Netherlands, Estonia, and Austria. Finally, an inclusive MIS is able to overcome the barrier of severe poverty to protect people in a situation of economic vulnerability as well. It is interesting that this dimension does not entirely overlap with the "institutional" distinction above: although countries in which the MIS plays a central role in their income maintenance system $\left(\right.$ Germany ${ }^{4}$ and Ireland) have a very inclusive MIS - as expected - this is also the case in some countries in which the MIS has a lastresort safety net function, such as France ${ }^{5}$, Finland, and Sweden.

\subsection{Expenditure}

Finally, a standard dimension to analyse social programmes and minimum income schemes is the overall expenditure level (Bahle et al., 2011). In Table 5, I differentiate among European minimum income schemes considering their level of expenditure as a percentage of the overall welfare expenditure. Clearly, this type of indicator is strongly influenced by the role of MISs in the overall income maintenance system for the working-age population. However, it is interesting that these dimensions do not entirely overlap. In Italy, the absence of a second-pillar unemployment compensation system should increase the relevance of MISs, which for the moment in the prevision of the government is still extremely residual. Conversely, the expenditure levels are (comparatively) quite high in France and Finland, considering that, in those countries,

\footnotetext{
${ }^{4}$ Relevantly, Germany would still be included in the 'High Degree of Inclusiveness' category also if we exclude the number of recipients $(1,264,000)$ of ALG II that had a job while receiving the benefit in order to allow the comparison with countries where in-work benefits were excluded. In this case, in fact, $137.8 \%$ of the severely poor individuals below 65 years old would be covered by the German MIS.

${ }^{5}$ Beneficiaries of the so-called RSA Activité, which can be considered an 'in-work benefit', are not included here in the calculation of recipients of the MIS in France.
} 
they still serve as residual safety nets below fairly comprehensive unemployment benefits systems. Less surprising is the high level of expenditure for MISs in Ireland and Germany, where - as already mentioned - means-tested minimum income schemes have a central role in the income maintenance system.

Table 5. Expenditure on MISs in European countries, 2015

\begin{tabular}{|c|c|c|c|}
\hline Country & $\begin{array}{c}\text { Total expenditure } \\
\text { (percentage of the } \\
\text { GDP) }\end{array}$ & $\begin{array}{l}\text { Total expenditure } \\
\text { (percentage of } \\
\text { welfare exp.) }\end{array}$ & $\begin{array}{l}\text { Expenditure } \\
\text { level }\end{array}$ \\
\hline Latvia & $0.03 \%$ & $0.22 \%$ & Low \\
\hline Bulgaria & $0.06 \%$ & $0.35 \%$ & Low \\
\hline Estonia & $0.08 \%$ & $0.47 \%$ & Low \\
\hline Italy (2018)* & $0.11 \%$ & $0.35 \%$ & Low \\
\hline Spain & $0.13 \%$ & $0.51 \%$ & Low \\
\hline Croatia & $0.15 \%$ & $0.70 \%$ & Low \\
\hline Czech Republic & $0.16 \%$ & $0.83 \%$ & Low \\
\hline Portugal & $0.16 \%$ & $0.62 \%$ & Low \\
\hline Lithuania & $0.21 \%$ & $1.33 \%$ & Medium \\
\hline Austria & $0.24 \%$ & $0.79 \%$ & Medium \\
\hline United Kingdom & $0.24 \%$ & $0.84 \%$ & Medium \\
\hline Sweden & $0.25 \%$ & $0.86 \%$ & Medium \\
\hline Belgium & $0.30 \%$ & $0.99 \%$ & Medium \\
\hline Luxembourg & $0.32 \%$ & $1.44 \%$ & Medium \\
\hline Finland & $0.35 \%$ & $1.12 \%$ & Medium \\
\hline Greece (2017)* & $0.43 \%$ & $1.63 \%$ & Medium (high) \\
\hline France** & $0.49 \%$ & $1.45 \%$ & Medium (high) \\
\hline Netherlands & $0.73 \%$ & $2.44 \%$ & High \\
\hline Denmark & $0.86 \%$ & $2.66 \%$ & High \\
\hline Ireland & $1.05 \%$ & $6.42 \%$ & High \\
\hline Germany & $1.39 \%$ & $4.75 \%$ & High \\
\hline
\end{tabular}

* The figures refer to government official estimates regarding minimum income expenditure.

**Expenditure for the RSA Activite not included in the analysis.

Source: Author's elaboration from the national statistical offices and the Eurostat online database.

\section{Active Inclusion Services from a Comparative Perspective}

Social assistance and minimum income benefits have deeply transformed in the last decades, so, examining aspects such as risk coverage and eligibility, the benefits 
structure, financing mechanisms, and organizational arrangements in place are not sufficient to capture their main properties. Nowadays, in fact, minimum income schemes in Europe are complex social policy benefits that combine income support with a block of services and programmes designed to help recipients to return to the labour market. In addition, since the late 1980s - and increasingly afterwards - access to MISs has been conditional on recipients" willingness to "activate" themselves in the labour market (Lodemel and Trickey, 2001; Moreira, 2008).

Schemes can - and actually do - realize this "activating" function very differently, as there is little agreement regarding the precise meaning of activation. Broadly defined, it is possible to conceive activation as a policy of combining negative and positive incentives with the ultimate purpose of helping minimum income recipients to become self-sufficient through paid employment (cfr. Moreira, 2008). Thus, it involves a number of policy instruments, such as legislation, financial incentives, and social or labour market services (Bonoli, 2011).

To make sense of the broad constellation of different measures and instruments, different authors have created typologies of active inclusion services (Barbier and Ludwig-Mayerhofer, 2004; Bonoli, 2011; Lodemel and Moreira, 2014; Marchal et al., 2017; Moreira, 2008). Despite relevant differences, these authors have in common an inclination to distinguish between two different approaches to activation (Marchal et al., 2017). The first one is narrower and tends to focus exclusively on incentivizing behaviours that increase labour market integration. It includes measures that offer both financial and non-financial stimuli intended to lower the reservation wage, such as low benefit levels, strict availability requirements, or time limits. The second approach tends to focus on the personal development of individuals through social investment-oriented 
measures. Theoretically, it aims to favour the improvement of individual capacities rather than the inducement of behavioural change (Marchal et al., 2017).

Building on these works - in particular those of Moreira (2008) and Weishaupt (2012) - I introduce a new typology to distinguish between different "worlds of activation services", by looking at the 'degree of conditionality' and at the types of programs associated with MISs. .

As to the first dimension, all European countries condition access to MIS on beneficiaries' willingness to 'activate' themselves. The basic idea is that, to bring more people into employment, it is necessary to impose stringent behavioural rules on MIS beneficiaries. Good indicators of this type of approach are the presence of more stringent assessments regarding job availability, greater recourse to sanctions, and a broader definition of a suitable job offer. An example of strong conditionality requirements is Germany, where, to avoid losing the entitlements, beneficiaries: a) have to perform all medical and/or psychological examinations agreed with the assigned "personal assistant"; b) during working days, have to be traceable by their personal assistant to the address that they provided and be available if requested to attend the job centre; c) have to respect all the tasks included in the integration agreement and in particular take up all measures for labour market integration and never cause its breakup; d) have to accept reasonable employment; and e) have to behave appropriately to avoid preventing the conclusion of an employment contract. In the case of a breach, the scheme will cut the benefits in terms of the standard rate by $30 \%$. The second breach will cause a cut of $60 \%$. After the third breach, the recipient will lose the benefits in terms of ALG II totally (Petzold, 2013). The sanctions are even stronger for beneficiaries under the age of 25 years. 
Many European countries have introduced such stringent conditionality requirements - especially in the north and in German-speaking continental countries. In Table 6, I report the results of the comparative research that Frazer and Marlier (2016) coordinated, which distinguished between three "levels of conditionality" associated with MISs: the first one is very strict, the second is limited, whereas the third is characterized by the complete absence of behavioural requirements. It is noticeable that in Europe, in 2015, no countries attached no strings to minimum income benefits, although experimentation in this direction has been launched in Finland and in some cities in the Netherlands.

Table 6. Conditionality of MISs in Europe

\begin{tabular}{ccc}
\hline Very strict & Limited conditionality & No conditionality \\
\hline Germany, Italy, Lithuania, & Austria (de facto), Belgium, \\
Latvia, Luxembourg, & Bulgaria, Czech Republic, \\
Netherlands, Portugal, & Denmark, Greece, Ireland, \\
United Kingdom & Spain, Finland, France, \\
& Sweden
\end{tabular}

Source: Frazer and Marlier 2016

The second dimension focuses on the type of programs associated with MIS, in order to assess whether these are exclusively labour-market related programs or rather MIS engage beneficiaries in a multi-level and multi-dimensional strategy that intends to reverse their situation of need. In the latter sense, the search for a job has the same priority as recovering from health problems, finding suitable accommodation, and so on (Guibentif and Bouget, 1997, pp. 14-18).

In this particular dimension, particularly interesting is the research that Marchal and Van Mechelen (2017) carried out, which built an indicator to distinguish between different active inclusion instruments available to minimum income beneficiaries. In 
Table 7, I report some of the results of their research, in particular on two dimensions, which they called Enabling and Service, to capture whether programmes associated with social assistance benefits have only a work-related scope or instead a wider scope. The former (service) assesses whether the beneficiaries of MISs have real "access to quality social services" through an index that takes into consideration the combination of the range of services available to MIS recipients and their burden of childcare costs. The latter (enabling) instead evaluates whether beneficiaries have access (also) to services that should foster their human capital development. The idea is that the better countries perform in these index, the more their active inclusion strategy have a broader scope than aimed at simply kick-starting beneficiaries back to work.

Table 7. Activation profile of minimum income schemes

\begin{tabular}{lccc}
\hline Country & Enabling & Service & Activation \\
\hline Bulgaria & 0.00 & 0.18 & Work-oriented \\
\hline Estonia & 0.35 & 0.09 & Work-oriented \\
\hline Portugal & 0.47 & 0.00 & Work-oriented \\
\hline Czech Republic & 0.50 & 0.00 & Work-oriented \\
\hline United Kingdom & 0.50 & 0.00 & Work-oriented \\
\hline Lithuania & 0.25 & 0.55 & Mixed \\
\hline Netherlands & 0.50 & 0.36 & Mixed \\
\hline France & 0.75 & 0.13 & Mixed \\
\hline Italy & 0.50 & 0.45 & Mixed \\
\hline Luxembourg & 0.75 & 0.27 & Mixed \\
\hline Germany & 0.75 & 0.43 & Empowerment \\
\hline Austria & 0.82 & 0.55 & Empowerment \\
\hline Finland & 0.87 & 0.55 & Empowerment \\
\hline Belgium & 0.75 & 0.82 &
\end{tabular}

Source: Author's elaboration from Marchal and Van Mechelen (2017).

Combining features in terms of sanctions and conditionality with the types of programmes associated with MISs allows me to provide a basic descriptive table regarding active inclusion regimes in Europe (Table 8). What emerges is a complex 
picture, as four types of active inclusion profile become apparent. In Bulgaria and Latvia, limited conditionality and the presence of few services associated with MISs seem to imply that the social assistance programmes are still mainly Passive. A very strictly work-oriented activation model combined with a strong conditionality is typical of a Workfare type. This type of active inclusion regime has a strong focus on work requirements, sanctions, time limits and exclusively labour market related services (Lodemel and Trickey, 2001), and it is typical of Estonia, the United Kingdom, the Netherlands, Portugal, and Italy. The presence of very strict conditionality combined with services that aim to empower recipients is typical of Luxembourg and Germany, which seem to have adopted a Paternalistic type of activation profile, as the individual agency of beneficiaries is not fully respected but 'inclusion' is not conceived exclusively in terms of labour market integration. Finally, the availability of a wide ranges of services combined with limited conditionality is typical of an Enabling regime. The countries in the sample that seems to have taken more steps towards an enabling activation regime are Austria, Finland, Belgium, Denmark, and Sweden.

Table 8. Inclusion regimes of MISs in Europe

\begin{tabular}{|c|c|c|c|}
\hline Country & Activation & Conditionality & Inclusion Regime \\
\hline Bulgaria & Work-oriented & Limited & Passive \\
\hline Czech Republic & Work-oriented & Limited & Passive \\
\hline Estonia & Work-oriented & Very strict & Workfare \\
\hline Portugal & Work-oriented & Very strict & Workfare \\
\hline United Kingdom & Work-oriented & Very strict & Workfare \\
\hline Netherlands & Mixed & Very strict & Paternalistic \\
\hline Italy & Mixed & Very strict & Paternalistic \\
\hline Germany & Empowerment & Very strict & Paternalistic \\
\hline Luxembourg & Empowerment & Very strict & Paternalistic \\
\hline France & Mixed & Limited & Enabling \\
\hline Austria & Empowerment & Limited & Enabling \\
\hline
\end{tabular}




\begin{tabular}{llll}
\hline Finland & Empowerment & Limited & Enabling \\
\hline Belgium & Empowerment & Limited & Enabling \\
\hline Denmark & Empowerment & Limited & Enabling \\
\hline Sweden & Empowerment & Limited & Enabling \\
\hline
\end{tabular}

\section{Minimum Income Schemes in Europe: a typology.}

In Europe, minimum income schemes (MISs) differ not exclusively in terms of generosity, duration, eligibility requirements, conditionality, and overall expenditure but also in terms of territorial configuration (Table 9) (Holsh and Kraus, 2011; Kazepov and Barberis, 2012).

In some cases, countries finance and regulate MISs at the national level, whereas subnational governments' role is limited to the implementation of active inclusion services. This is what I call here a centralized model, and it is typical of Anglo-Saxon (Ireland and United Kingdom) countries and France.

Table 9. Territorial configuration of MISs in Europe

\begin{tabular}{|c|c|c|}
\hline Model & Role of the regional level & Countries \\
\hline Centralized & $\begin{array}{l}\text { Implementation } \\
\text { Active inclusion policies }\end{array}$ & $\begin{array}{l}\text { Ireland, United Kingdom } \\
\text { France, Portugal }\end{array}$ \\
\hline $\begin{array}{l}\text { Integrated/ } \\
\text { Decentralized }\end{array}$ & $\begin{array}{l}\text { Regulatory (except basic framework } \\
\text { law and minima) } \\
\text { Implementation } \\
\text { Active inclusion policies }\end{array}$ & $\begin{array}{l}\text { Sweden, Denmark, Finland, } \\
\text { Belgium } \\
\text { Germany, } \\
\text { Netherlands }\end{array}$ \\
\hline $\begin{array}{l}\text { Uncoordinated } \\
\text { decentralization }\end{array}$ & $\begin{array}{l}\text { Financing } \\
\text { Legislative } \\
\text { Implementation } \\
\text { Active inclusion policies }\end{array}$ & $\begin{array}{l}\text { Austria } \\
\text { Italy (until 2018) } \\
\text { Spain } \\
\text { Switzerland }\end{array}$ \\
\hline
\end{tabular}


In the Nordic countries - but also in Germany and the Netherlands - the central state establishes the minimum standards that it must guarantee throughout the country, but subnational governments are particularly involved in regulating and organizing the provision of minimum income schemes. This implies that local governments cannot legally deny benefits and services to those fulfilling eligibility criteria (Minas and Overbye, 2010) but that, at the same time, they have the responsibility to manage and (at least partially) finance the scheme and enjoy a high degree of autonomy in implementing the benefits (Kazepov and Barberis, 2012). As for territorial differentiation, in this model, there are differences in the provision of benefits and services beyond the minimum standard. This is why I refer to the model as an integrated decentralized model. Finally, in some countries, sub-national governments have assumed a crucial role in the anti-poverty field in the absence of a national legislative framework setting minimum standards, guaranteeing coordination between different instruments, substituting regional governments in the case of non-compliance, and facilitating the assurance of the diffusion of best practices. This is the case in Austria (apart from a break between 2010 and 2016), Switzerland, Spain, and, until very recently, Italy. As the Italian and the Spanish case outline, the uncoordinated decentralized model allows the emergence of strong territorial inequalities (Kazepov and Barberis, 2012; Natili, 2016).

This brief reconstruction has confirmed that minimum income schemes are complex social policy measures, combining monetary benefits and a broad number of services, which vary extensively across Europe and can be studied from different angles. They have different roles in the income maintenance system, so it is necessary to know which social programmes exist "above" before trying to compare their effectiveness. They should countervail poverty and material deprivation, so it is 
necessary to assess their adequacy - in terms of their ability to guarantee a decent standard of living to poor individuals - and to verify the presence of formal and/or informal conditions that might impede the access of a relevant part of the population in need. Furthermore, nowadays, one of their main goals is to help beneficiaries to participate fully in the society and - when possible - to help in finding an appropriate job. Schemes, however, realize this differently, and, although sometimes individual agency is not respected and the only type of services that they provide to beneficiaries are labour market-related, in other cases they adopt a multidimensional approach that should help individuals to solve their issues in different domains of their life. Finally, the definition of who is responsible for minimum income benefits also differs quite extensively across Europe. This is not only important in terms of territorial equality - as a more decentralized system may create less egalitarian systems, in which discretionary powers become particularly manifest (Nelson, 2013) - but also possibly conditions their ability to achieve the goal of relieving poverty (Hölsch and Kraus, 2011).

All these dimensions have important distributive and normative consequences. Moreover, combining these different dimensions, country-specific configurations of minimum income schemes emerge, which are very revealing about "the normative foundations behind them and the notion of solidarity they pursue, as addressing in a non-neutral way key concerns about who are the poor, who deserve to be assisted, in what forms and by whom" (cfr. Madama, 2015). Here - after having underlined in the previous paragraph also differences in the governance of MIS - we construct a typology based on two particular dimensions: their ability to protect poor individual and the type of active inclusion services attached to MIS. The ability to protect from poverty depend on many different things, but in particular on their generosity and on their availability in case of need. While the former dimension is rather straightforward, benefit availability 
as we have seen is more complex and depend on different factors, such as: availability of other type of social policy benefits - i.e. the role of MIS in the institutional configuration of income maintenance benefits - type of eligibility requirements, and administrative features. Here, we consider benefit 'available' when the degree of inclusiveness is high, or when it is medium but the role of MIS in the income maintenance system is residual.

Table 10. Minimum Income Schemes in Europe: a typology

\begin{tabular}{lccccc}
\hline Country & $\begin{array}{c}\text { Institutional } \\
\text { Role }\end{array}$ & Generosity & Coverage & Expenditure & $\begin{array}{c}\text { Inclusion } \\
\text { Regime }\end{array}$ \\
\hline Bulgaria & $*$ & Low & Low & Low & Passive \\
\hline Croatia & $*$ & Low & Low & $*$ \\
\hline Czech & Residual & Low & Low & Passive
\end{tabular}

Republic

\begin{tabular}{lccccc}
\hline Italy (2018) & Safety & Low & Low & Low & Paternalistic \\
\hline Latvia & $*$ & Low & Low & Low & $*$ \\
\hline Portugal & Residual & Low & Low & Low & Workfare \\
\hline Spain & Residual & Medium & Low & Low & $*$ \\
\hline United & Central & Low & Low & Low & Workfare
\end{tabular}

Kingdom

\begin{tabular}{lccccc}
\hline Estonia & $*$ & Low & Medium & Low & Workfare \\
\hline Lithuania & $*$ & Medium & Low & Medium & Workfare \\
\hline & & PROTECTIVE & &
\end{tabular}

\begin{tabular}{lllccc}
\hline Germany & Central & Medium & High & High & Paternalistic \\
\hline Greece & Residual & Medium & Medium & Medium & \\
(2017) & & & & & $*$ \\
\hline
\end{tabular}

\begin{tabular}{lllccc}
\hline Luxembourg & Safety & High & $*$ & Medium & Paternalistic \\
\hline Netherlands & Safety & High & Medium & High & Paternalistic \\
\hline Ireland & Central & Medium & High & High & $*$ \\
\hline \multicolumn{5}{c}{ ENABLING } \\
Austria & Residual & High & Medium & Medium & Enabling \\
\hline
\end{tabular}




\begin{tabular}{lccccc}
\hline Belgium & Safety & High & $*$ & Medium & Enabling \\
\hline Denmark & Safety & High & Medium & High & Enabling \\
\hline Finland & Residual & Medium & High & Medium & Enabling \\
\hline France & Residual & Medium & High & Medium & Enabling \\
\hline Sweden & Residual & Low & High & Medium & Enabling \\
\hline
\end{tabular}

Combining these elements, we construct our typology of minimum income benefits (Table 10). In several countries, minimum income schemes are Inadequate, in the sense that they are not able to provide a minimum degree of protection to poor individuals while their active inclusion services seem weakly developed. This is the case in Bulgaria, Croatia, Czech Republic, Latvia, and Italy (as for 2018).

When a fairly low level of protection is combined with a very strong workfare approach, I call MIS Sanctionatory. In those cases, MIS are mainly instruments to make poor people change their behaviour and participate to the labour market. This is the situation in Spain, Portugal, United Kingdom, Estonia and Lithuania, where - to be fair - MIS is slightly more protective that in the Inadequate model. The Protective model usually combine a fair level of generosity and inclusiveness with strong activation requirement, usually limited to job searching activities. Poor individual are thus protected from the main vagaries of life, but there is less respect of their "human agency" and a general tendency to give greater importance to labour markets needs over poor individual choices and desires. Finally, in the Enabling model, income support is generous, people in poverty have the possibility to access to those benefits, and they have access to a broad range of active inclusion services - which are not exclusively aimed to make people return to the labour market no matter in what conditions. This model is typical of Northern countries, Belgium and France. 


\section{Conclusions}

This article had two main aims. First, it aimed to describe that minimum income schemes differ quite extensively nowadays in Europe, highlighting that the perceived common path towards active inclusion hides in reality different worlds of anti-poverty safety nets. This differentiation goes beyond the well-known 'three worlds' distinction of Esping-Andersen (1990) as well as classification based on 'social assistance regimes' (Bahle et al., 2011; Gough et al. 1997; Gough 2001). To this regard, particularly interesting divergences emerge both in Southern and Eastern Europe, where countries appear to have reacted differently to the challenges posed by Great Recession (Natili et al. 2018). Indeed, Lithuania and Estonia, as well as Greece (and, previously, Portugal) have made more steps forward in strengthening MIS compared to some of their neighbourhood countries. Similarly, French-speaking countries have different MIS compared to other countries in Continental Europe, with less pronounced conditioning elements, resulting in safety nets more similar to Scandinavian countries.

Second, and relatedly, the article unveils the institutional logic of the various anti-poverty safety nets around Europe. Combining dimensions related to protectiveness of last resort safety nets (coverage, generosity, expenditure) with others concerning their activation profile, this article shows that these two dimensions are correlated, and countries that invest more in the protection of the poor population tend to invest also more in their active inclusion. At the same time, a distinction emerges also between countries with similar 'degree of protectiveness', and while some countries consider MIS as instrument to protect against poverty and to modify deviant behaviour of the (irresponsible?) poor, others have a more nuanced approach, including recipients in the construction of individual path towards social and labour market inclusion. 
Alber, J. (1981), 'Government Responses to the Challenge of Unemployment: The Development of Unemployment Insurance in Western Europe' in P. Flora and A. J. Heidenheimer (Eds.) Development of Welfare States in Europe and America (New York: Routledge).

Angelin, A., Johansson, H., Koch, M. and Panican, A. (2013), National Report: Sweden, Deliverable D5.5, Project Combating Poverty in Europe: Reorganising Active Inclusion through Participatory and Integrated Modes of Multilevel Governance

Bahle, T., Hubl, V. and Pfeifer, M. (2011), The Last Safety Net. A Handbook of Minimum Income Protection in Europe (Bristol: The Policy Press).

Barbier, J.-C. and Ludwig-Mayerhofer, W. (2004), 'The many worlds of activation', European Societies, vol. 6 (4), pp. 423-36.

Bonoli, G. (2011), 'Active labour market policy in a changing economic context' in Clasen, J. and Clegg, D. (Eds.) Regulating the Risk of Unemployment: National Adaptations to Post-Industrial Labour Markets in Europe (Oxford: Oxford University Press).

Clasen, J. and Clegg, D. (Eds.) (2011), Regulating the Risk of Unemployment: National Adaptations to Post-Industrial Labour Markets in Europe (Oxford: Oxford University Press).

Clegg, D. (2013), 'Dynamics and Varieties of Active Inclusion: A Five Country Comparison' Deliverable D5.6, Project Combating Poverty in Europe: Reorganising Active Inclusion through Participatory and Integrated Modes of Multilevel Governance.

Crepaldi, C., Da Roit, B., Castegnaro, C. and Pasquinelli, S. (2017), Minimum Income Policies in EU Member States, Study for the EU Parliament, Committee on Employment and Social Affairs.

Eurofound (2015), 'Access to social benefits: Reducing non-take-up', Publications Office of the European Union, Luxembourg.

Ferrera, M. (2000), 'Targeting Welfare in a Soft State: Italy's Winding Road to Selectivity' in N. Gilbert (Ed.), Targeting Social Benefits: International Perspective and Trends (New Brunswick: Transactions).

Ferrera, M. (2005), The Boundaries of Welfare (Oxford: Oxford University Press).

Ferrera, M., Hemericjck, A. and Rhodes, M. (2000) 'The future of the European welfare state: Managing diversity for a prosperous and cohesive Europe', Report for the Portuguese Presidency of the European Union, Luxembourg: Office for Official Publications of the European Communities.

Figari F, Matsaganis M, Sutherland H. (2013), 'Are European social safety nets tight enough? Coverage and adequacy of Minimum Income schemes in $14 \mathrm{EU}$ countries' International Journal of Social Welfare, vol. 22, pp. 3-14.

Fleckenstein, T. (2008), 'Restructuring welfare for the unemployed: the Hartz legislation in Germany' Journal of European Social Policy, vol. 18 (2), pp. 177188.

Frazer, H. and Marlier, E. (2016), 'Minimum Income Schemes. A Study of National Policies', European Social Policy Network, European Commission.

Gough, I. (2001) 'Social assistance regimes: a cluster analysis' Journal of European Social Policy 11(2): 165-170.

Gough, I., Eardley, T., Bradshaw, J., Ditch, J. and Whiteford, P. (1997) 'Social Assistance in OECD Countries', Journal of European Social Policy 7(1): 17-43. 
Granaglia, E. and Bolzoni, M. (2016), Il reddito di base (Roma: Ediesse).

Guibentif, P. and Bouget, D. (1997), As Políticas Rendimento Mínimo na União Europeia (Lisboa: União das Mutualidades Portuguesas).

Hemerijk, A. (2012), Changing welfare states (Oxford: Oxford University Press).

Immervoll, H. (2010), 'Minimum Income Benefits in OECD Countries: Policy Design, Effectiveness and Challenges' OECD Social, Employment and Migration Working Papers 100, OECD Publishing.

Jessoula, M., Matsaganis, M. and Natili, M. (2015), 'Strengthening minimum income protection in Southern and Eastern Europe? Pressures from within and from beyond' Paper Presented at the $22^{\text {nd }}$ International Conference of Europeanists, Paris, France.

Kazepov, Y. (Ed.) (2010), Rescaling Social Policies: Towards Multilevel Governance in Europe (European Centre Vienna: Ashgate).

Kazepov, Y. and Barberis, E. (2012), 'Social Assistance Governance in Europe: Towards a Multilevel Perspective' in Marx and Nelson (Eds.) Minimum Income Protection in Flux. (Basingstoke: Palgrave Macmillan).

Lødemel I. and Schulte, B. (1992) Social assistance: A part of social security or the Poor Law in new disguise?, Brussels: European Institute of Social Security.

Lodemel, I. and Moreira, A. (Eds.) (2014), Activation or Workfare? Governance and the Neo-Liberal Convergence (Oxford; Oxford University Press).

Lødemel, I. and Trickey, H. (Eds) (2001), 'An offer you can't refuse': Workfare in international perspective (Bristol: The Policy Press).

Madama, I. (2015), 'The Welfare State and Redistribution. Remarks on the Policy and Politics of the Robin Hood Principle at Work' in Riva, N., Madama, I., Bistagnino, G. The Politics of Redistribution. An Interdisciplinary Dialogue on the Foundations of the Welfare State LPF Working Paper 4/2015, Centro Einaudi, Torino.

Marchal, S., Marx, I. and Van Mechelen, N. (2016), 'Minimum income protection in the austerity tide' IZA Journal of European Labor Studies vol. 5 (4).

Marchal, S., and Van Mechelen, N. (2017), 'A New Kid in Town? Active Inclusion Elements in European Minimum Income Schemes' Social Policy \& Administration, Vol. 51, 171-194.

Marx, I. and Nelson, K. (Eds.) (2012), Minimum Income Protection in Flux. (Basingstoke: Palgrave Macmillan).

Matsaganis, M., Paulus, A., and Sutherland, H. (2008) 'The take up of social benefits', Institute for Social and Economic Research, Research Note 6/2008.

Minas, R. and Overbye, E. (2010), 'The territorial organization of European social assistance schemes' in Y. Kazepov (Ed.) Rescaling Social Policies: Towards Multilevel Governance in Europe (Surrey: Ashgate).

Moreira, A. (2008), The Activation Dilemma. Reconciling the Fairness and Effectiveness of Minimum Income Schemes in Europe (Bristol: The Policy Press).

Natili, M. (2016), 'The Unexpected Institutionalization of a Minimum Income in Spain', LPF Working Paper 2/2016, Centro Einaudi, Torino.

Natili, M., Jessoula, M., Madama, I. and Matsaganis, M. (2018) 'The Right(s) and minimum income in hard times: Southern and Eastern Europe compared', European Societies, Published online: 11 Jul 2018.

Nelson, K. (2013), Social assistance and EU poverty thresholds 1990-2008. Are European welfare systems providing just and fair protection against low income? European Sociological Review, vol. 29 (2), pp. 386-401. 
Petzold, N. (2013), 'National report: Germany', Deliverable D5.1, Combating Poverty in Europe: Re-organising Active Inclusion through Participatory and Integrated Participatory and Integrated Modes of Multilevel Governance

Picot, G. (2012), Politics of Segmentation: Party Competition and Social Protection in Europe (London: Routledge, 2012).

Rat, C. (2009), 'The impact of minimum income guarantee schemes in Central and Eastern Europe' in Cerami, A. and Vanhuysse, P. (Eds.) Post-Communist Welfare Pathways. Theorizing Social Policy Transformations in Central and Eastern Europe, (Basingstoke: Palgrave Macmillan).

Rosanvallon, P. (1995), La Nouvelle Question Sociale: Repenser l'Etat Providence (Paris: Seuil).

Sacchi, S. (2013), 'Le esperienze europee di contrasto alla povertà. Che cosa possiamo imparare?' Unpublished Paper.

Schmid, G. and Reissert. B. (1996), 'Unemployment Compensation and Labour Market Transitions', in G. Schmid el al. (eds) International Handbook of Labour Market Policy and Evaluation. (Cheltenham and Brookfield. UK: Edwar Elgar).

Vesan, P. (2012), Le politiche del lavoro in Ferrera (Ed.) Le politiche sociali (Bologna: Il Mulino).

Van Mechelen, N. and Marchal, S. (2012), 'Struggle for Life: Social assistance benefits, 1992-2009' in Marx and Nelson (Eds.) (2012) Minimum Income Protection in Flux. (Basingstoke: Palgrave Macmillan).

Weishaupt, J.T. (2012), 'Origin and Genesis of Activation Policies in 'Old'Europe: Towards a Balanced Approach?' in Marx and Nelson (Eds.) (2012) Minimum Income Protection in Flux. (Basingstoke: Palgrave Macmillan). 